MOTORYN Ruslan,

DSc (Economics), Professor, Professor at the Department of Statistics and Econometrics Kyiv National University of Trade and Economics 19, Kyoto str., Kyiv, 02156, Ukraine
SLUSARCZYK Boguslaw, DSc (Economics), Professor, Institute of Economics and Finance University of Rzeszow 16C aleja Tadeusza Rejtana, 35-310, Rzeszow, Poland

E-mail:boguslaw.slusarczyk@gmail.com ORCID: 0000-0003-0567-8470

ZEGLEN Patrycja,

$\mathrm{PhD}$ (Economics), Associate Professor, Institute of Economics and Finance University of Rzeszow 16C aleja Tadeusza Rejtana, 35-310, Rzeszow, Poland

E-mail:pzeglen@ur.edu.pl ORCID: 0000-0002-6815-6488

\title{
E-COMMERCE IN THE ERA OF GLOBALIZATION
}

The paper aims to outline the development of electronic commerce. The economic impact of e-commerce is explored, statistical estimation on e-commerce degree of development in the era of globalization is considered. The key tendencies of e-commerce market in the world are investigated. In particular, we examined the types and special features of e-commerce online markets, and described the most popular specialized trade sites.

Keywords: information technology, e-marketing, e-commerce, Internet, e-business.

Background. Economic development in the world in recent years mainly happens due to the development of modern technology and the Internet. In many cases, this has led to a change in the way of doing business to the so-called "e-commerce". The aim of the study is to present e-commerce in many aspects as a form of modern trade in the era of globalization. With the advent of new internet technologies, more and more companies are starting to use e-commerce to maximize their profits. Online shopping has become much easier because people can use their mobile phones and computers for e-commerce in more affordable ways. The use of Internet technology in business also facilitates the transition to international markets, as it removes the geographical limitations of the traditional business model, thereby reducing communication costs. Research hypothesis - e-commerce as a form of modern trade in the era of globalization. E-commerce markets are booming. The Internet market will grow at a rate of $56 \%$ in 2015-2020. Traditional markets for the same period expect growth of $2 \%$.

Asia is currently number one in terms of trade growth, and more than $70 \%$ of exports are industrial goods. The top three are China, the United States

(C) Motoryn R., Slusarczyk B., Zeglen P., 2021

ISSN 1727-9313. ВICHИК КНTEУ. 2021. 
and Germany in 2018. China and South Korea are the leading traders in emerging economies. Compared to goods trade, services are also developing rapidly in all regions of the world. In 2018, emerging economies such as China, India and Singapore were the leading exporters, while the United States and China were the largest importers.

Analysis of recent research and publications. Anil Khural defines e-commerce as the use of computer, Internet and general software to send and receive product specifications and drawings; applications, purchase orders and invoices; and any other type of data that needs to be passed on to customers, suppliers, employees or the public [1]. Roger Clark e-commerce is defined as the trading of goods and services through telecommunication and telecommunication tools [2]. Jerry Ellison also defines e-commerce as an electronic contract for the exchange of values using information and communications technology [3]. E-commerce is also defined as doing business online, selling goods and services that are delivered offline, as well as products that can be "digitized" and delivered online such as software [4].

The origins of e-commerce date back to the 1960s, when the first solutions for e-commerce in the form of modems were developed. The B2B sector has been used for X.25 transactions since the mid-1970s, Frame Relay began to be used in the late 1980s, and ATM networks in the mid-1990s [5]. These solutions continue to work, but they usually limit the sphere of data transfer on the Internet. Circulation of documents is carried out using the EDI technique. "EDI is the electronic exchange of commercial or administrative data between different computer systems using an agreed data formatting standard. If EDI is used instead of paper documents sent by traditional mail (e.g. order, order confirmation, invoice), the equivalents of these documents are provided in the form of computer files. The files are sent electronically to the recipient's computer system and then automatically processed by an application that interprets there salting data structures" [6]. Minitel was a pioneer of e-commerce in the $\mathrm{B}_{2} \mathrm{C}^{1}$ and $\mathrm{B} 2 \mathrm{~B}$ sector [7]. This technology consisted in connecting telephone lines to alphanumeric terminals that were connected to servers via a telephone network [8]. Due to the ease of use, this solution has become very popular, mainly in the service sector, such as: dating sites, phone books or, for example, the sale or booking of train tickets. The turning point was the use of web browsers for network services.

This solution became popular because it was available to anyone who had access to a personal computer. Except for the circulation of information and documents, another element of e-commerce is the ability to pay online and their security. Thus, in the mid-90s of the last century, the first companies, such as First Virtual or Cyber Cash, appeared to make it possible to make online

\footnotetext{
${ }^{1}$ The term "B2C" comes from the English "business to consumer" (literally - "business to consumer"). This term means the sale of goods and services to individuals. Means the customer buys something for his personal use. The term B2B stands for "business to business". Likewise, this concept means the sale of goods and services for the needs of companies. 
payments. During this period, the first Internet bank Security First Network Bank was created [9]. Currently, the electronic transaction sector has become very popular and offers solutions such as transfers using payment cards, interbank transfers or deposits.

One of the largest and most famous global online payment companies eBay, which in 2019 had more than 180 million active users, has also left its mark in e-commerce [10]. The group includes PayPal, which provides fast e-transaction services and has had a decisive influence on the development of e-commerce. The genesis of e-commerce is inextricably linked to the genesis of the development and emergence of the Internet. The origins of the Internet date back to the late 1960s with the creation of the ARPANET network [11].

It was initiated by the United States Department of Defense to monitor, support, and increase scientific productivity through communication between computer-equipped research institutions. Twenty years later in England, Tim Berners-Lee laid the foundations of the World Wide Web service in the form of a space where you could find saved data by entering the appropriate address [12].

The first.com domain was created in the 1980s, and the first virus was released online under the name Morris Worm [13]. The following events appeared, such as the first electronic payment, the first blogs, graphic banners on websites and streaming.

The aim of the article. The subject of the study is global e-commerce markets. The aim is to show the holistic nature of e-commerce as the dominant form of modern commerce in the era of globalization. The research paper uses the method of desk research, i.e. analysis of available data. It consists in obtaining and researching existing information, which is the basis for new information according to the purpose of the study. Case studies are especially useful in the previous phase of projects, when the ideas are not yet clear and data are sought to articulate the opportunities and risks of the initiatives. The main source of data were the reports of the Dutch company E-commerce foundation [14]. Given the above, elements of e-commerce that show its global nature were selected. Each of the individual elements, such as: the B2C and B2B sectors1, the use of the Internet, e-commerce tools, payments, goods or consumer groups, which are represented on world markets, have been characterized to show the transnational nature and large-scale e-commerce.

Materials and methods. The research is based on scientific publications, periodicals, Internet resources, as well as materials and analytical forecasts of the Global Business Data Platform-Statista, the World Bank, the World Trade Organization, the State Statistics Service of Ukraine and professional community. The paper uses the method of desk research, i.e. analysis of available data. It consists in obtaining and researching already available information, which is the basis for new reports according to the purpose of the study. Methods of analysis and synthesis, abstraction and generalization, statistical methods are applied. 
Results. In the modern society with network globalization and economic globalization, every day a large amount of data are sent over the network, some of which involve the important information related to political, military, commercial, financial, and personal privacy [15]. These processes became possible mainly due to the development of the Internet, which forced many companies to use it in order to stay in the market. For a long time, despite the high growth of e-commerce, almost every product can be purchased online only since 2010 . Availability and ease of transactions have had a decisive impact on the development of e-commerce. At the same time, the transport and logistics infrastructure is developing strongly, the expansion of which has led to a significant reduction in the cost of product delivery. The factors mentioned above that stimulate the growth of e-commerce have led to increasing of competition in the online-store market. This leads to increasing in innovation, which instead of increasing the volume of operations leads to the improving of quality of services. As the history of globalization shows, the world economy has dominated the local one. As a result, there has been a steady development of world trade, easier rotation of labor factors and economic growth worldwide.

The current state of any country's economy largely depends on accurate estimates, forecasting, effective planning and management of e-commerce.

The modern e-commerce system is a complex, integrated organizational and production system, the elements of which are constantly changing and interacting. Achieving these goals in the face of increased competition between e-commerce leads to an increase in the number and complexity of production processes, analysis, planning, management, internal and external relations with suppliers, intermediaries and more. The rapid growth of e-commerce is creating challenges for companies trying to develop e-commerce strategies. This is especially difficult given the continuous flow of new information technologies. Nevertheless, companies are promoting their e-commerce strategies, partly fearing that they will lose customers if they do not have an e-commerce strategy.

The intensity of use of e-commerce services by different organizations largely depends on the number of Internet users in a particular country.

Due to the high population density and rapid development of information technology, Asia occupies a leading position. It is also worth paying attention to the countries of Europe and America, as these regions are highly developed, and the introduction of Internet technologies is part of actively improving business efficiency. Retail e-commerce worldwide in 2017 amounted to $\$ 2.3$ trillion. In the same year, the revenues of the 3 largest online stores (amazon.com, apple.com, wallmart.com) amounted to almost $\$ 100$ billion. According to the results of the United Nations Conference on Trade and Development in 2015, Ukraine ranked 58th among 130 countries in the world in terms of conditions for the development of e-business. As of 2016, more than $36 \%$ of Internet users in Ukraine regularly made purchases online, and $91 \%$ of consumers made purchases online at least once. Following the results of last year, Ukraine was ahead of all other European countries on such indicator as rates of growth 70 
of sales on the Internet - for our country this indicator made $35 \%$. This objecttively leads to the formation of commercial structures that operate on the Internet and open new opportunities for business entities, creating a new business environment [16].

Globalization and e-commerce are expected to change the economic structure of countries. E-commerce not only reduces communication costs, but also increases flexibility in finding activities. Globalization of business has been declared a key factor in the spread of e-commerce. Large global firms are likely to use e-commerce more than smaller firms.

Companies facing foreign competition are under strong pressure to implement technologies such as e-commerce, which will allow them to protect or increase market share and operate more efficiently.

Firms operating outside their home country may be more interested in reducing operating costs through information technology. You can save your money and time by using Internet for transactions and coordination, and big stream of data - for approximation and optimization of commodity flow in supply chain. Globalization affects the introduction of e-commerce between B2B and B2C in different ways. Global companies are more involved in B2B, and smaller multinationals are more involved in B2C.

Speaking of e-commerce segments, by the end of 2017, B2C e-commerce sales will reach $\$ 2.3$ trillion worldwide. The B2B e-commerce market is more than twice the $\mathrm{B} 2 \mathrm{C}$ market and is constantly growing. Given the rise of globalization, the fact that the US share of global e-commerce sales continues to decline is not alarming. The US share of e-commerce is expected to reach $16.9 \%$ in 2020 (compared to $22.2 \%$ in 2015). As a result, the lion's share of global B2B e-commerce sales is now located outside of North America and Europe. In an increasingly global market, it is harder than ever to keep a company competitive. There are ruthless forces influencing the modern business environment such as consumer power, global trade, Internet opportunities, deregulation, emerging markets, rapidly declining product life cycle, fierce competition, etc. E-commerce is a revolutionary tool in the global market. This can fundamentally change the way of doing business. It is an interdisciplinary tool that has had a profound impact on business, government, education, financial services, and more.

Globalization is a phenomenon that has led to the integration of regionnal economies, societies and cultures through communications, transport and trade. This is closely linked to economic globalization, which means the integration of national economies into the international economy through trade, foreign direct investment, capital flows, migration, technology proliferation and a military presence. However, the phenomenon of globalization is usually the result of a combination of economic, technological, sociocultural, political and biological factors. In the global market, companies discover that old trading strategies are becoming obsolete. Increasing competition has led to the rapid development of new products and, as a consequence, shortened products life cycles. 
Global gross product is equal to the total world nominal GDP. As can be seen from the figure 1, GDP has shown an upward trend throughout the whole period from 1960 to 2018. The World Bank estimates that the world economy has grown from $\$ 11.39$ trillion in 1960 to $\$ 82.63$ trillion in 2018 at constant prices in 2010. It is an increase in more than 7 times. The highest growth rate was $6.7 \%$ in 1964, while the lowest decline rate was recorded in $2009-1.7 \%$. In 2017, the sectoral structure of the world economy was: agriculture $6.4 \%$, industry $30 \%$ and services $63 \%$.

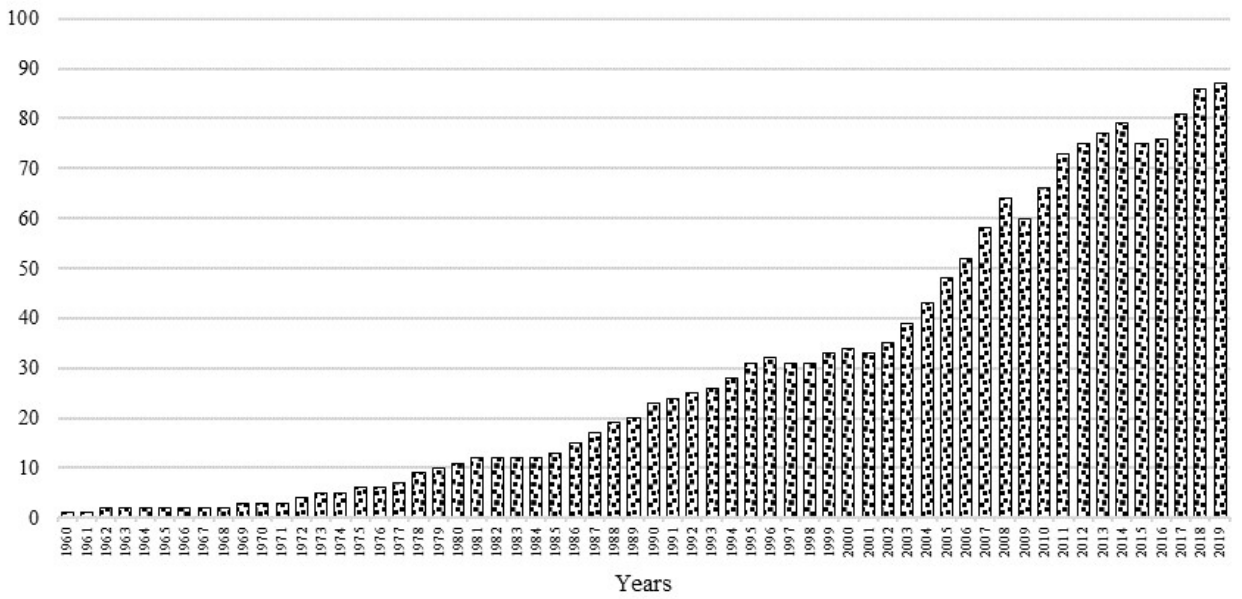

Figure 1. Global gross domestic product, 1960-2019, \$ billions

Source: developed by the authors by data [17].

Each of the columns (figure 2) on the chart shows the amount of digital buyers worldwide in billions. This value is growing every year. Between 2014 and 2019, this number increased by about 600 million.

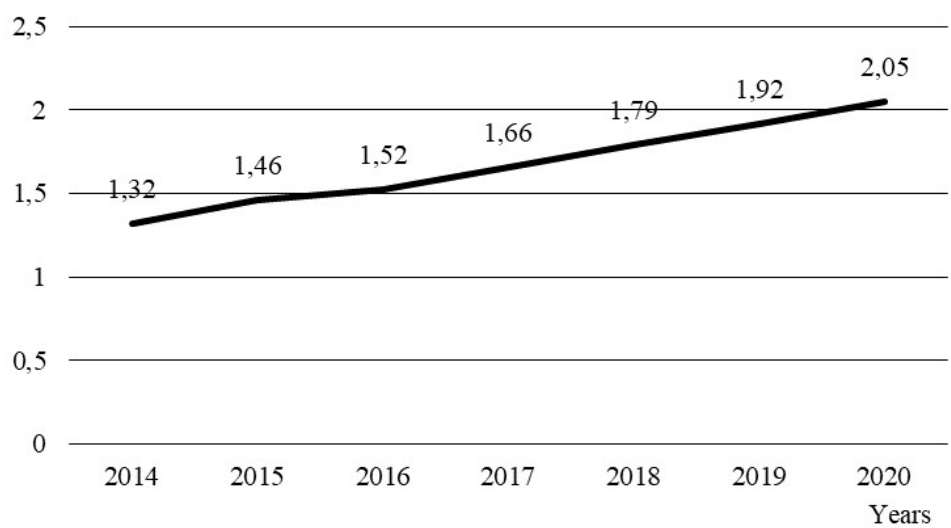

Figure 2. The amount of digital buyers worldwide, 2014-2020, \$ billions

Source: developed by the authors by data [18].

Continuous growth is also expected in the coming years. The forecast for 2021 predicts an increase of more than 200 million digital buyers, amounting to 2.14 billion. For comparison, the total number of Internet shoppers in Ukraine in 2016 was 3.7 million people. 
The chart in figure 3 shows e-commerce retail worldwide from 2014 to the 2023 forecast. In 2019, e-commerce retail sales worldwide amounted to $\$ 3453$ billion, the forecast for 2023 almost doubled to $\$ 6542$ billion. The analyzed period together with the forecast for the next years shows a constant upward trend. According to forecasts, sales will almost double over the next 4 years.

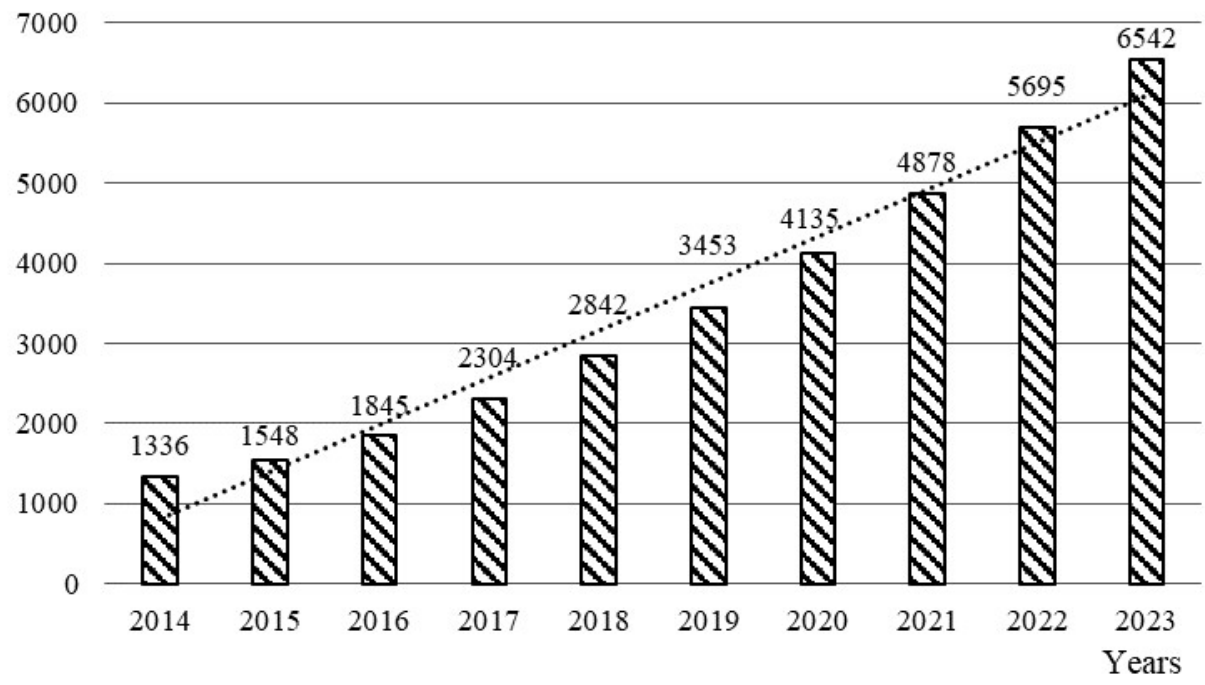

Figure 3. Retail sales of e-commerce worldwide, 2014-2023, \$ billions

Source: developed by the authors by data [19].

Table presents data of retail Ecommerce Sales for the top 10 countries. The United States deserves special attention.

Top 10 countries, ranked by retail ecommerce sales, 2018-2019, $\$$ billions [20]

\begin{tabular}{|l|c|c|c|}
\hline Country & 2018 & 2019 & \% change \\
\hline China & 1520.10 & 1934.78 & 27.3 \\
\hline US & 514.84 & 586.92 & 14.0 \\
\hline UK & 127.98 & 141.93 & 10.9 \\
\hline Japan & 110.96 & 115.40 & 4.0 \\
\hline South Korea & 87.60 & 103.48 & 18.1 \\
\hline Germany & 75.93 & 81.85 & 7.8 \\
\hline France & 62.27 & 69.43 & 11.5 \\
\hline Canada & 41.12 & 49.80 & 21.1 \\
\hline India & 34.91 & 46.05 & 31.9 \\
\hline Russia & 22.68 & 26.92 & 18.7 \\
\hline
\end{tabular}

The interest rate (figure 4) indicates how much e-commerce is in US total sales. In 2017, sales reached \$ 901535 million, a year earlier - \$ 887555 million, and at the beginning of the research period $\$ 663119$ million. The highest number was in 2014 and amounted to $\$ 903421$ million. 


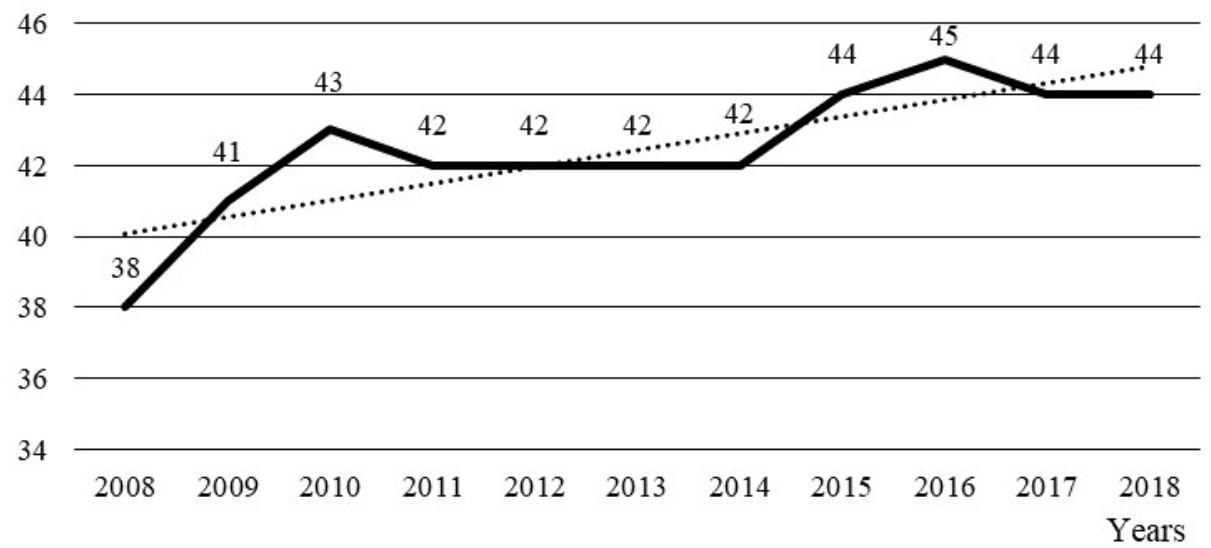

Figure 4. The share of electronic commerce in total sales of US medium companies, 2008-2018, \%

Source: developed by the authors by data [21].

There was a steady increase in e-commerce and total sales except 2015 and 2016. For comparison, the share of electronic commerce in total sales in Ukraine in 2016 was $3.3 \%$, but the growth rate of e-commerce in Ukraine was $27 \%$, and the total volume of retail trade $-6 \%$ in 2016 compared to 2015 . Moreover, in Poland the share of electronic commerce in total sales increase from $12 \%$ in 2015 to $13 \%$ in 2016 and in 2020 was $18 \%$.

The chart in figure 5 shows the global amount of e-commerce in the B2B sector in 2013-2019. The amount of gross goods in e-commerce transactions between enterprises increased from $\$ 5.83$ trillion in 2013 to $\$ 7.66$ trillion in 2017, which is an increase of more than $20 \%$.

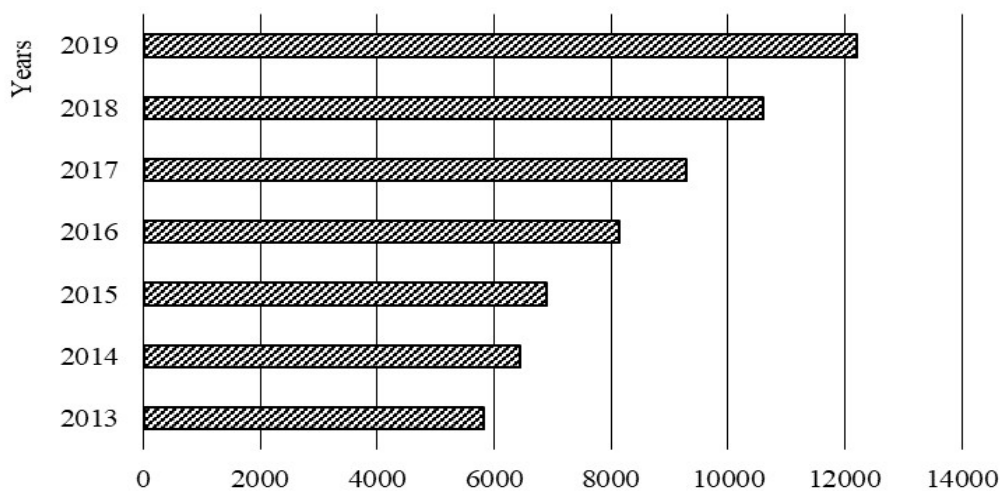

Figure 5. World amount of e-commerce B2B gross merchandise volume (GMV), 2013-2019, \$ billions

Source: developed by the authors by data [22].

The chart in figure 6 shows the increase in B2C e-commerce sales worldwide from 2012 to 2018. 


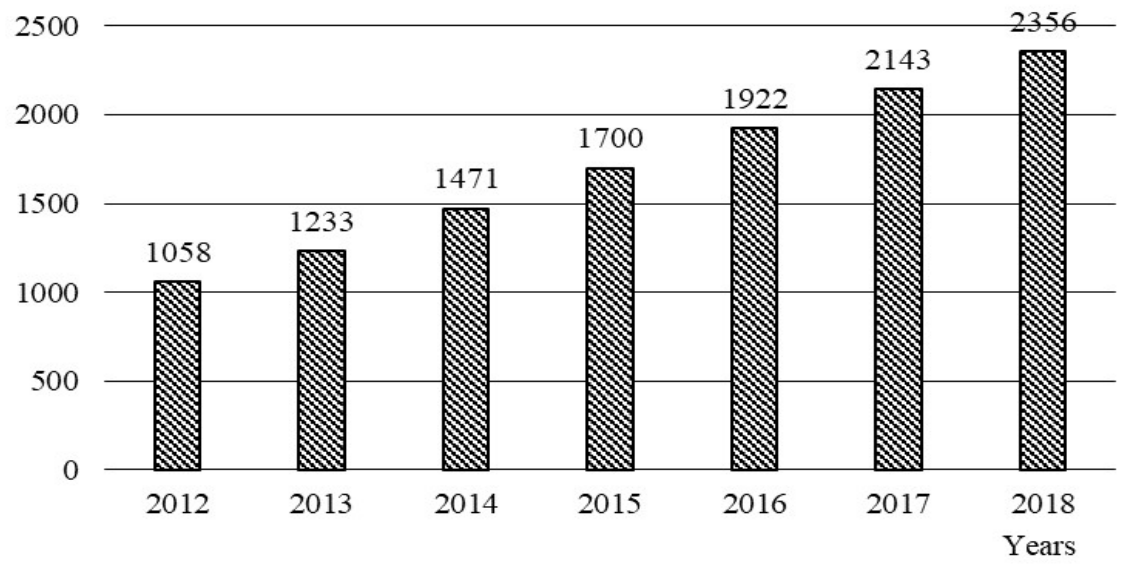

Figure 6. E-commerce B2C sales worldwide, 2012-2018, \$ billions

Source: developed by the authors by data [23].

The steady upward trend over the past 6 years has caused more than double the growth of global sales from $\$ 1058$ billion in 2012 to $\$ 2356$ billion in 2018.

Conclusion. The aim of the study was to present e-commerce as a form of modern trade in the era of globalization. Considering the preconditions of the process of globalization and e-commerce, the development of international e-commerce in the context of globalization or cross-border e-commerce, the authors of the study came to the following conclusions:

- The transition from the traditional form of trade in the era of globalization to electronic has become a natural technological consequence. This progress has also led to a new era of globalization known as Globalization 4.0.

- As the history of globalization shows, the global economy has dominated the local one. As a result, there has been a steady development of world trade, easier rotation of labor factors and economic growth around the world.

- The health of any country's economy depends largely on accurate assessment, forecasting, effective planning and management of e-commerce.

- Activities in the field of e-commerce are very wide. It covers the business sector (B2B), retail trade (B2C) or direct exchange between consumers through commercial portals $(\mathrm{C} 2 \mathrm{C})$.

- E-commerce has a great influence on the development of international trade. This allowed the use of the latest technologies for trade, such as the Internet, BIG DATA or cloud computing.

- The trend of e-commerce often forces companies to change their business model. The variety of personalized products provided through e-commerce in some ways forces companies to follow this trend, wanting to stay in the game.

- To meet customers' expectations, it is extremely important to increase the choice of products and provide relevant information about them.

- The biggest advantage of e-commerce is the lowest cost of providing and transmitting information. 
- The main area of improvement of e-commerce is security. In particular, we are talking about the security of the Internet, money transactions and customer data.

- China, the United States and Germany are among the top three in terms of e-commerce.

- Cross-border e-commerce has revolutionized traditional commerce with significant implications for both buyers and sellers.

- Cross-border e-commerce has lifted restrictions imposed by state borders. This has created and, above all, the global success of companies such as Amazon or Alibaba.

- Thanks to CBEC, the online payments sector has developed significantly, which, for example, has allowed company in this field to become one of the largest in the world, i.e. PayPal.

- Cross-border e-commerce has also significantly developed the logistics branch.

The different needs of companies in this area have been implemented by many solutions that have helped not only large corporations but also companies in the small and medium business sector. Every year, at least one billion consumers worldwide buy online. This activity is developing more and more every year. Customers choose it for convenience, and because of competitive prices.

Summarizing the conclusions mentioned above, we can say that e-commerce is the dominant form of modern trade in the era of globalization.

\section{REFERENCES}

1. Anil, K. (2019). Introduction to e-commerce. Retrieved from http://www.ddegjust.ac.in/ studymaterial $/ \mathrm{mcom} / \mathrm{mc}-201 . p d f$. Accessed 30.12.2020 [in English].

2. Clarke, R. (2015). Electronic Commerce Definition. Retrieved from http://www.rogerclarke.com/EC/ECDefns.html Accessed 30.12.2020 [in English].

3. Allison, J. (2015). E-commerce: Exactly what is it. Retrieved from http://www.drjerryallison.hubpages.com Accessed 30.12.2020 [in English].

4. Coppel, J. (2000). E-commerce: Impact and policy challenges. OECD Ec. (45-60) [in English].

5. Sheremet, A. D. (2012). Forms of e-commerce and its composition in the digital economy. Bul. of Dnip. Nat. Un. of Rail. Tr. N. after. Ac. V. Lazaryan. 41, 311-315 [in English].

6. Wiesław, M., Grudzewski, I., \& Hejduk, K. (2004). Zarządzanie wiedzą w przedsiębiorstwach., Difin, Warszawa 2004 [in Polish].

7. Tsarev, V. V., \& Kantarovich, A. A. (2001). Economics, organization and planning of commercial activities of Internet companies [in English].

8. Nanehkaran, Y. (2013). An Introduction To Electronic Commerce. Int. J. of Sc. \& Tech. Res. 2(4), 190-193 [in English].

9. Security First Network Bank. Retrieved from https://www.usbanklocations.com/ security-first-network-bank-29162.shtml. Accessed 30.12.2020 [in English].

10. Statista. Retrieved from https://www.statista.com/statistics/242235/number-ofebays-total-active-users Accessed 30.12.2020 [in English]. 
11. Walden, David C. (2003). "Looking back at the ARPANET effort, 34 years later". Living Internet. East Sandwich, Massachusetts. Retrieved from livinginternet.com [in English].

12. Ideas worth spreading. Retrieved from https://www.ted.com/speakers/tim_berners_lee Accessed 30.12.2020 [in English].

13. Kehoe, Brendan P. (2007). "The Robert Morris Internet Worm". Computer Science \& Artificial Intelligence Laboratory (CSAIL). Massachusetts Institute of Technology [in English].

14. Ecommerce foundation. Retrieved from https://www.ecommercefoundation.org Accessed 30.12.2020 [in English].

15. Zhe-Ming, Lu, \& Shi-Ze, Guo (2017). In Lossless Information Hiding in Images [in English].

16. Electronic commerce in Ukraine (2016). Figures and facts. Retrieved from https://webexpert.com.ua/ua/elektronna-komertsiya-v-ukrayini-2016. Accessed 30.12.2020 [in English].

17. The World Bank. Retrieved from https://data.worldbank.org/indicator/NY. GDP.MKTP.CD?name_desc=true [in English].

18. Statista. Retrieved from https://www.statista.com/statistics/251666/number-ofdigital-buyers-worldwide [in English].

19. Statista. Retrieved from https://www.statista.com/statistics/379046/worldwide-retaile-commerce-sales [in English].

20. eMarketer. Global Ecommerce (2019). Retrieved from https://www.emarketer.com/ content/global-ecommerce-2019 [in English].

21. Statista. Retrieved from https://www.statista.com/statistics/185122/us-e-commercevalue-of-sales-of-merchant-wholesale-trade [in English].

22. Statista. Retrieved from https://www.statista.com/statistics/705606/global-b2be-commerce-gmv [in English].

23. Statista. Retrieved from https://www.statista.com/statistics/261245/b2c-e-commercesales-worldwide [in English].

The article was received by the editors 02.01.2021.

\section{глобалізації. \\ Моторин Р., Шлюсарчик Б., Жеглен П. Електронна комерція в епоху}

Постановка проблеми. Економічна ситуація у світі за останні роки загалом зумовлена розвитком сучасних технологій та Інтернету, щзо насамперед змінило спосіб ведення бізнесу, зокрема ие "Електронна комериія". 3 появою нових інтернеттехнологій компанї здебільшого починають використовувати електронну комериію, щзоб максимізувати свій прибуток.

Аналіз останніх досліджень і публікацій. Попри дискусійний характер розуміння сутності електронної комериії, наукова спільнота констатує невпинне зростання ролі інтернет-технологій у веденні бізнесу.

Метою статті є визначення иілісного представлення електронної комериії у багатьох аспектах як форми сучасної торгівлі в епоху глобалізації.

Матеріали та методи. Дослідження проведено на основі наукових видань, матеріалів Глобальної платформи бізнес-даних - Statista, Світового Банку, Світової організації торгівлі, Державної служби статистики Украйни та професійних організаиій. У ході роботи застосовано метод desk research, тобто аналіз наявних даних, який полягає в отриманні та вивченні вже наявної інформації, щзо є основою для нових матеріалів згідно з поставленою метою. Методичною базою дослідження стали аналіз і синтез, абстрагування та узагальнення, статистичні методи.

Результати дослідження. Розглянуто вплив електронної комериії на економіку, зроблено статистичну оцінку ступеня розвитку електронної комериії в епоху 
глобалізації. Досліджено ключові тенденції розвитку ринку електронної комериї у світі. Виокремлено типи та особливості інтернет-ринків електронної комериії, визначено найпопулярніші спеціалізовані торгові сайти.

Водночас зосереджено увагу на елементах електронної комериії, щзо мають глобальний характер. Доведено, щуо електронна комериія не тільки зменшує витрати на спілкування, але й збільшуе гнучкість у пошуку продуктів. Глобалізація бізнесу $\epsilon$ ключовим фактором поширення електронної комерції.

Висновки. Перехід від традиџійної форми торгівлі в епоху глобалізачії до електронної став природним технологічним наслідком. Цей прогрес також привів до нової ери глобалізації. Тенденції розвитку електронної комериії часто змушують компанії змінювати свою бізнес-модель. Різноманітні та персоналізовані продукти, щзо постачаються у рамках електронної комериії, певним чином змушують компанії, які бажають залишатися в грі, слідувати изій тенденції.

Ключові слова: інформаційні технології, електронний маркетинг, електронна комерція, Інтернет, електронний бізнес. 